\title{
Glacial $\mathrm{CO}_{2}$ cycle as a succession of key physical and biogeochemical processes
}

\author{
V. Brovkin ${ }^{1, *}$, A. Ganopolski ${ }^{2}$, D. Archer ${ }^{3}$, and G. Munhoven ${ }^{4}$ \\ ${ }^{1}$ Max Planck Institute for Meteorology, Bundesstr. 53, 20146, Hamburg, Germany \\ ${ }^{2}$ Potsdam Institute for Climate Impact Research, Telegraphenberg A31, 14473 Potsdam, Germany \\ ${ }^{3}$ Department of the Geophysical Sciences, University of Chicago, 5734 S Ellis Ave, Chicago, IL 60637, USA \\ ${ }^{4}$ Institute of Astrophysics and Geophysics, University of Liège, 4000 Liège, Belgium \\ *also at: Potsdam Institute for Climate Impact Research, Potsdam, Germany
}

Correspondence to: V. Brovkin (victor.brovkin@zmaw.de)

Received: 13 May 2011 - Published in Clim. Past Discuss.: 30 May 2011

Revised: 5 December 2011 - Accepted: 2 January 2012 - Published: 9 February 2012

\begin{abstract}
During glacial-interglacial cycles, atmospheric $\mathrm{CO}_{2}$ concentration varied by about $100 \mathrm{ppmv}$ in amplitude. While testing mechanisms that have led to the low glacial $\mathrm{CO}_{2}$ level could be done in equilibrium model experiments, an ultimate goal is to explain $\mathrm{CO}_{2}$ changes in transient simulations through the complete glacial-interglacial cycle. The computationally efficient Earth System model of intermediate complexity CLIMBER-2 is used to simulate global biogeochemistry over the last glacial cycle (126 kyr). The physical core of the model (atmosphere, ocean, land and ice sheets) is driven by orbital changes and reconstructed radiative forcing from greenhouses gases, ice, and aeolian dust. The carbon cycle model is able to reproduce the main features of the $\mathrm{CO}_{2}$ changes: a 50 ppmv $\mathrm{CO}_{2}$ drop during glacial inception, a minimum concentration at the last glacial maximum 80 ppmv lower than the Holocene value, and an abrupt 60 ppmv $\mathrm{CO}_{2}$ rise during the deglaciation. The model deep ocean $\delta^{13} \mathrm{C}$ also resembles reconstructions from deep-sea cores. The main drivers of atmospheric $\mathrm{CO}_{2}$ evolve in time: changes in sea surface temperatures and in the volume of bottom water of southern origin control atmospheric $\mathrm{CO}_{2}$ during the glacial inception and deglaciation; changes in carbonate chemistry and marine biology are dominant during the first and second parts of the glacial cycle, respectively. These feedback mechanisms could also significantly impact the ultimate climate response to the anthropogenic perturbation.
\end{abstract}

\section{Introduction}

Ice core records of atmospheric $\mathrm{CO}_{2}$ concentration through the last 800,000 years show the carbon cycle amplifying the climate forcing from variations in Earth's orbit (Augustin et al., 2004). This positive climate-carbon cycle feedback could weaken or even possibly reverse present-day fossil fuel $\mathrm{CO}_{2}$ uptake by the natural carbon cycle. Despite much effort over the last decades, a process-based explanation of the carbon cycle feedbacks responsible for the glacial-interglacial $\mathrm{CO}_{2}$ cycles remains elusive. Mechanisms proposed to explain the glacial cycles of atmospheric $\mathrm{CO}_{2}$ include changes in sea surface temperatures (SSTs), nutrients, circulation, and carbonate chemistry (Archer et al., 2000; Sigman and Boyle, 2000; Toggweiler et al., 2006; Kohfeld and Ridgwell, 2009). The main focus has been to explain the low atmospheric $\mathrm{CO}_{2}$ concentration of about $190 \mathrm{ppmv}$ at the last glacial maximum (LGM) about 21000 years ago. Most of these studies were built on the assumption that the carbon cycle was in equilibrium at that time (e.g. Hain et al., 2010; Kurahashi-Nakamura et al., 2010). However, the carbon cycle is most likely never in steady state during a glacial cycle because of the long time scales of many of the biogeochemical processes. Our goal is to explain the $\mathrm{CO}_{2}$ concentration not only for the LGM snapshot but through the whole glacial cycle, focusing on a possible sequence of mechanisms that drive $\mathrm{CO}_{2}$ changes (Köhler and Fischer, 2006; Peacock et al., 2006; Watson et al., 2000). 
The challenge is to explore these mechanisms using the Earth system models that include 2- or 3-dimensional models of oceanic circulation, a key driver of oceanic biogeochemistry.

\section{Methods}

\subsection{The model}

The CLIMBER-2 model includes six components of the Earth system: atmosphere, ocean, sea ice, land surface, terrestrial vegetation and ice sheets. The first five components are represented by coarse-resolution modules of intermediate complexity (Brovkin et al., 2002; Petoukhov et al., 2000). The ice-sheet component is represented by the three-dimensional polythermal ice-sheet model SICOPOLIS (Greve, 1997). The ice-sheet model is applied only to the Northern Hemisphere (NH). The carbon cycle model includes land carbon, oceanic biogeochemistry, a model for marine biota, and a sediment model (Archer, 1996; Brovkin et al., 2007). Weathering rates scale to runoff from the land surface (Munhoven, 2002), the coral reef growth depends on the sea level rise (Kleypas, 1997), the scale of nutrients utilization in sub-Antarctic ocean is proportional to the dust deposition derived from Antarctic ice core (Augustin et al., 2004), and volcanic outgassing has been assumed to have remained constant through the whole glacial cycle. The carbon cycle components in past studies were run off-line, i.e. simulated changes in atmospheric $\mathrm{CO}_{2}$ were not fed back into the radiative calculation, which evolved as a function of the history of equivalent $\mathrm{CO}_{2}$ derived from ice core data.

\subsection{Experimental setup of the physical model}

The experimental set-up followed a recent simulation of the last glacial cycle without carbon fluxes (Ganopolski et al., 2010). We prescribed temporal variations in the orbital parameters (Berger, 1978) and the equivalent $\mathrm{CO}_{2}$ concentration, which accounts for changes in three major greenhouse gases (GHGs $-\mathrm{CO}_{2}, \mathrm{~N}_{2} \mathrm{O}$ and $\mathrm{CH}_{4}$ ) derived from the Antarctic ice cores (Barnola et al., 1987; Augustin et al., 2004; Monnin et al., 2004), and aeolian dust deposition (Mahowald et al., 1999) (Fig. 1). As initial conditions for the physical climate system, we used equilibrium climate and ice sheets simulated for the present-day orbital configuration and GHG concentrations. The model was run from $126 \mathrm{kyr}$ BP for 136000 years, i.e. for 10000 years into the future. This was done to estimate the equilibration time of the global carbon cycle after the last deglaciation. For the future, GHG concentrations were kept constant at the preindustrial level, i.e. the human influence on climate was not considered. Under the influence of the orbital forcing alone, CLIMBER-2 simulates a slow growth of the ice sheets in the Northern Hemisphere which is explained by favorable orbital configuration but small eccentricity and, therefore, weak orbital forcing. Simulated changes in climate and ice volume over

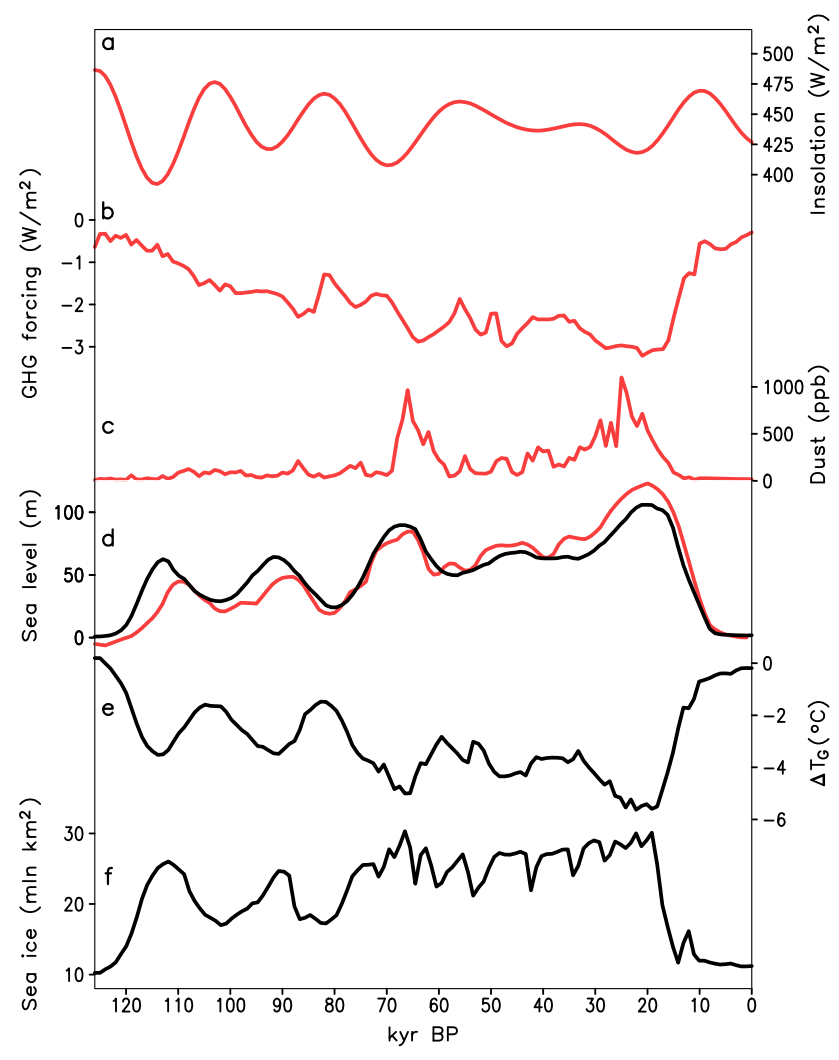

Fig. 1. Prescribed forcings and results of physical model simulation of the last glacial cycle. (a) Orbital forcing (illustrated by the June insolation at $65^{\circ} \mathrm{N}$ ); (b) radiative forcing of GHGs, (c) concentration of dust in the EPICA ice core; (d) changes in the simulated ice sheet volume (thick black line) and reconstructed sea level change (Waelbroeck et al., 2002) (thin red line), in meters of sea level change relative to $126 \mathrm{kyr} \mathrm{BP}$; (e) changes in the simulated global surface air temperature; (f) simulated annual mean sea ice area in the Southern Hemisphere.

the past 126000 years agree favourably with paleoclimate reconstructions (Ganopolski et al., 2010, see Fig. 1d).

\subsection{Experimental setup of biogeochemistry}

\subsubsection{Ocean carbon cycle}

The physical ocean component of the model is essentially the same as the one used in a previous glacial equilibrium simulation (Brovkin et al., 2007). The only important difference is that the background vertical diffusivity of the biogeochemical tracers in the ice-free Southern Ocean south of $50^{\circ} \mathrm{S}$ was enhanced by an order of magnitude, i.e. to ca. $10^{-3} \mathrm{~m}^{2} \mathrm{~s}^{-1}$ (under the sea ice, the standard values of $10^{-4} \mathrm{~m}^{2} \mathrm{~s}^{-1}$ was retained). This was done to obtain $\mathrm{CO}_{2}$ outgassing in the Southern Ocean (SO) consistent with recent empirical estimates of about $0.4 \mathrm{GtC} \mathrm{yr}^{-1}$ (Gruber et al., 2009). The standard version of CLIMBER-2, similar to many other even much more sophisticated ocean models (Fletcher et al., 
2007), considerably underestimates the magnitude of $\mathrm{CO}_{2}$ outgassing in the SO. We found that enhanced outgassing in the SO considerably increased the sensitivity of the atmospheric $p \mathrm{CO}_{2}$ to changes in sea ice cover in the SO. For example, in the standard model version (without enhanced vertical diffusivity in the $\mathrm{SO}$ ) under present-day climate conditions, the complete insulation of the $\mathrm{SO}$ (south of $50^{\circ} \mathrm{S}$ ) from the atmosphere leads to changes in atmospheric $p \mathrm{CO}_{2}$ by only 4 ppm (Archer et al., 2003), while in the version with enhanced outgassing, the SO insulation leads to a $20 \mathrm{ppm}$ decrease in atmospheric $\mathrm{CO}_{2}$. The model version with the enhanced southern outgassing simulates glacial/interglacial $\mathrm{CO}_{2}$ variations of ca. $10 \mathrm{ppm}$ higher than the standard model version. Enhanced diffusivity was only applied to the passive (biogeochemical) tracers. Although the effect of enhanced vertical diffusivity on active tracers (temperature and salinity) is small, we prefer to keep the physical component of the model unchanged to avoid inconsistencies with our previous results (Brovkin et al., 2007).

To evaluate the effect of modified parameter values on the biogeochemistry, we performed an equilibrium simulation of the model in the pre-industrial setup. In the Annex, the model performance is compared with observations in terms of distribution of essential biogeochemical tracers $\left(\mathrm{PO}_{4}\right.$, dissolved organic carbon, alkalinity, and ${ }^{14} \mathrm{C}$ ). Transient simulations of the oceanic carbon and CFC-11 uptakes throughout the last century are provided for comparison as well. In general, the performance of the oceanic biogeochemistry model for preindustrial state is very similar to the results from the previously published CLIMBER-2 versions (Brovkin et al., 2002, 2007).

\subsubsection{Inventories of ${ }^{12} \mathrm{C}$ and ${ }^{13} \mathrm{C}$}

Global inventories of ${ }^{12} \mathrm{C}$ and ${ }^{13} \mathrm{C}$ in the model experiments are conservative. The atmospheric $\mathrm{CO}_{2}$ concentration was calculated from the total carbon inventory equation:

$$
\begin{aligned}
& \left({ }^{i} C^{\mathrm{atm}}(t)-{ }^{i} C_{0}^{\mathrm{atm}}\right)+\left({ }^{i} C^{\mathrm{oc}}(t)-{ }^{i} C_{0}^{\mathrm{oc}}\right) \\
& +\left({ }^{i} C^{\text {land }}(t)-{ }^{i} C_{0}^{\mathrm{land}}\right)=\int_{0}^{t}\left({ }^{i} F^{\mathrm{volc}}(t)\right. \\
& \left.-{ }^{i} F^{\text {atm_cons }}(t)\right)+\left({ }^{i} F^{\text {weath }}(t)\right)-\left({ }^{i} F^{\text {burial }}(t)\right) \mathrm{d} t
\end{aligned}
$$

where the index $i$ denotes the carbon isotope $\left({ }^{12} \mathrm{C}\right.$ or $\left.{ }^{13} \mathrm{C}\right)$, ${ }^{i} \mathrm{C}$ stands for carbon isotope inventories (GtC) and ${ }^{i} F$ is for carbon isotope fluxes $\left(\mathrm{GtC} \mathrm{yr}^{-1}\right)$. Indices "atm", "oc", and "land" refer to atmospheric, ocean, and land compartments, respectively, $t$ is the model year starting from 0 at $126000 \mathrm{yr} \mathrm{BP}$, and the index 0 for carbon compartments is for the initial storages of carbon at the beginning of the simulations. ${ }^{i} F^{\text {volc }}$ is for volcanic outgassing of $\mathrm{CO}_{2}$ fixed to a value $0.066 \mathrm{GtC} \mathrm{yr}^{-1}$ with ${ }^{13} \mathrm{C}$ content of $6 \%$ (relative to the
Pee Dee Belemnite - PDB - standard). ${ }^{i} F^{\text {atm_cons }}$ is the atmospheric consumption of $\mathrm{CO}_{2}$ due to terrestrial weathering of both carbonate and silicate rocks, ${ }^{i} F^{\text {weath }}$ is the bicarbonate flux from the land to the ocean arising from continental weathering. The consumption of atmospheric $\mathrm{CO}_{2}$ and the production of riverine $\mathrm{HCO}_{3}^{-}$by continental weathering processes are calculated as a function of geographically distributed runoff (interactively simulated by the land surface module) and lithology (Amiotte-Suchet et al., 2003). ${ }^{i} F^{\text {burial }}$ is an interactively simulated $\mathrm{CaCO}_{3}$ burial on shelves (coral reefs) (Kleypas, 1997) and in the deep sea (Archer, 1991). Ocean carbon storage ${ }^{i} C^{o c}$ is for dissolved inorganic and organic carbon components in the ocean, including marine biota biomass. Land carbon compartment ${ }^{i} C^{\text {land }}$ is for vegetation biomass and soil carbon storages. In the land carbon cycle, we assumed that the decomposition of soil organic matter is slowed if annual mean temperatures fall below $-10^{\circ} \mathrm{C}$.

In Eq. (1), the land surface area accounted in the land carbon storage ${ }^{i} C^{\text {land }}$, weathering ${ }^{i} F^{\text {atm_cons }}$, and atmospheric $\mathrm{CO}_{2}$ consumption ${ }^{i} F^{\text {atm_cons }}$ was linearly scaled between pre-industrial and LGM land surface areas proportionally to the sea level. The ocean volume was also adjusted in accordance with the sea level. The total ocean alkalinity is calculated as a balance of alkalinity fluxes due to terrestrial weathering and burial of $\mathrm{CaCO}_{3}$ on shelves and in the deep ocean.

Atmospheric $\mathrm{CO}_{2}$ calculated from Eq. (1) (using a conversion factor of $0.47 \mathrm{ppm} \mathrm{GtC}^{-1}$ ) was not used as a radiative forcing for the atmospheric model component, which was driven by greenhouse gas concentrations reconstructed from Antarctic ice cores (see Sect. 2.2). This methodology assures that the carbon cycle is influenced by changes in the physical climate system. It should, however, be emphasized that there is no feedback of the simulated atmospheric $\mathrm{CO}_{2}$ concentration to climate. Although this approach is obviously limited, it is a useful first step in the analysis of glacial $\mathrm{CO}_{2}$ cycles within the model framework avoiding the effect of carbon cycle biases on climate.

\section{Initial conditions of the carbon cycle}

Initial conditions of the land and oceanic biogeochemistry were set up following a procedure used recently for initializing interglacial carbon cycle (Kleinen et al., 2010). Firstly, the model was run, with equilibrium conditions of $126000 \mathrm{BP}$ with $\mathrm{CO}_{2} \mathrm{kept}$ at the level of $280 \mathrm{ppmv}$. Ocean alkalinity was increased to get a carbonate sedimentation flux of $16 T_{\mathrm{mol}} \mathrm{yr}^{-1}$ in the deep ocean and $2 T_{\mathrm{mol}} \mathrm{yr}^{-1}$ on the shelves in order to simulate the maximum in $\mathrm{CaCO}_{3}$ preservation in the deep sea before the onset of the interglacial. Atmospheric $\delta^{13} \mathrm{CO}_{2}$ was initialized to $-6.7 \%$. The model was run with prescribed $\mathrm{CO}_{2}$ for 5000 years. In the transient simulations through the last glacial cycle, the carbonate accumulation on the shelves and in the deep sea was interactive with a shift towards carbonate accumulation in shallow 


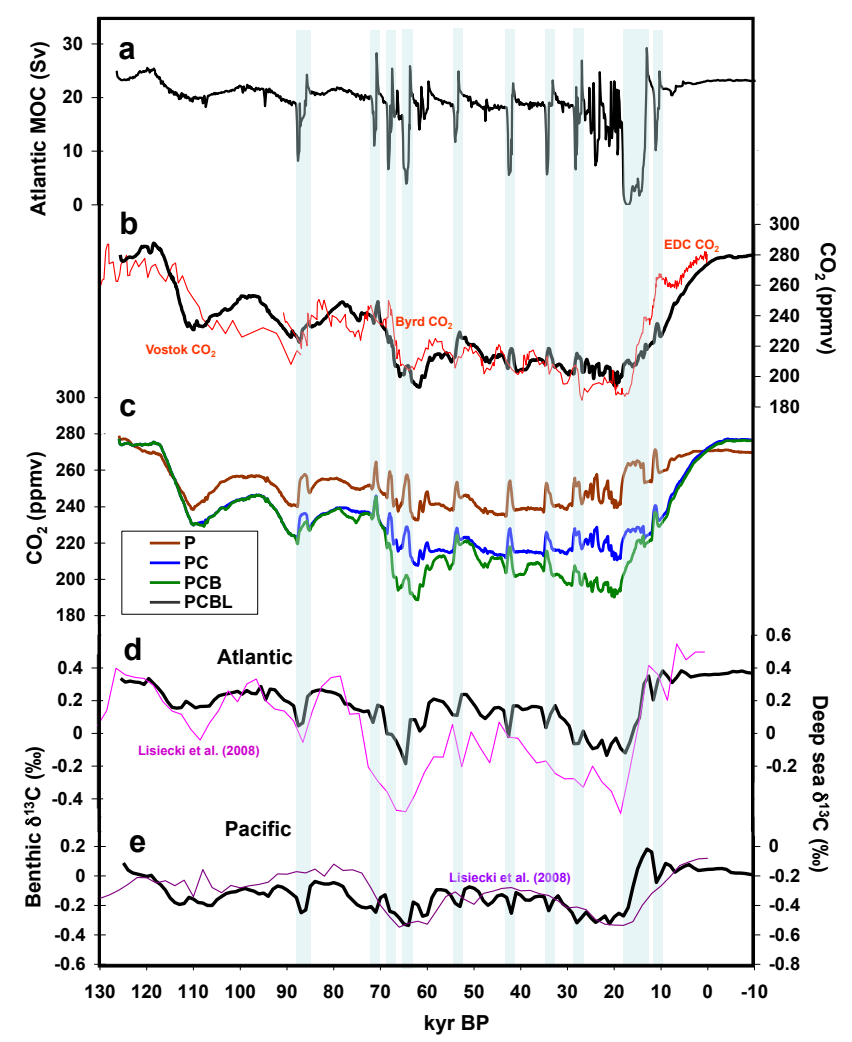

Fig. 2. Comparison of model results with geological records: (a) simulated Atlantic meridional overturning circulation in $\mathrm{Sv}$; (b) atmospheric $\mathrm{CO}_{2}$ concentration, simulation PCBL (thin black line), and Antarctic ice core reconstructions (Ahn and Brook, 2008; Barnola et al., 1987; Monnin et al., 2004) (thin red lines) in ppmv; (c) atmospheric $\mathrm{CO}_{2}$ concentration for simulations $\mathrm{P}, \mathrm{PC}$, and PCB (brown, blue, and green lines, respectively) in ppmv; (d) deep-sea $\delta^{13} \mathrm{C}$ for simulation PCBL (thick black line) and geological stack record for the Atlantic Ocean (Lisiecki et al., 2008) (thin pink line) in \%o; (e) the same as (d) but for Pacific Ocean.

waters during interglacials. This setup of initial conditions ensures that the ocean biogeochemistry is in equilibrium with the climate at the onset of interglacial while it is in transition from the glacial to interglacial state hereafter.

\section{Results and discussion}

\subsection{Transient experiments}

The physical part of the CLIMBER-2 model has been used to simulate the last glacial cycle, forced by changes in orbital forcing and greenhouse gases concentrations (Ganopolski et al., 2010). The model reproduces the temporal and spatial dynamics of the major Northern Hemisphere (NH) ice sheets, including the rapid glacial inception started at 120 to $118 \mathrm{kyr}$ BP (thousand years before present) (Fig. 1d). The global mean annual temperature decreases by about $6 \mathrm{~K}$ at

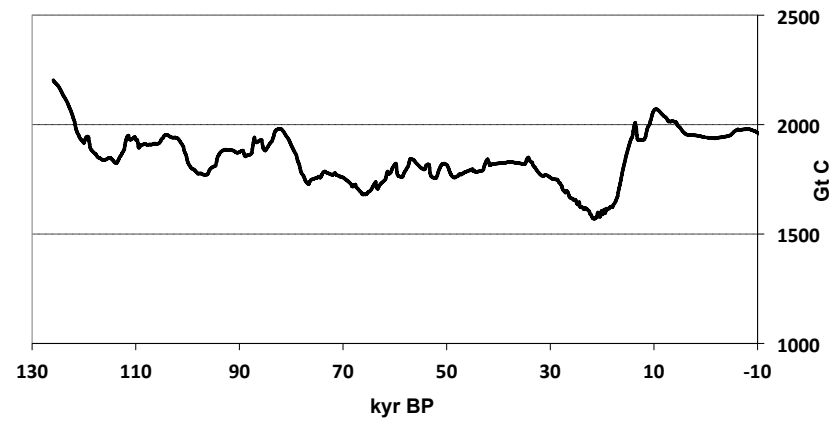

Fig. 3. Dynamics of the total terrestrial carbon storage (soil plus biomass in $\mathrm{GtC}$ ) in the PCBL simulation.

the LGM relative to pre-industrial (Fig. 1e) while the annual mean sea ice area in the Southern Hemisphere increases three-fold during the same period (Fig. 1f).

Here, we focus on the responses of various parts of the carbon cycle to the changes in the physical system. Simulation P includes the effects of physical mechanisms only (changes in SST, circulation, and sea level), PC adds changes in the carbonate chemistry (carbonate compensation, shift of carbonate sedimentation from shallow waters to the deep sea and vice versa, and weathering), PCB complements with changes in nutrient utilization by marine ecosystems (iron fertilization due to aeolian dust deposition), and PCBL finally adds land carbon dynamics. All simulations start from the same non-equilibrium conditions in oceanic carbonate chemistry at $126 \mathrm{kyr} \mathrm{BP}$ and continue to 10000 years after the present day without considering anthropogenic forcings. The atmospheric $\mathrm{CO}_{2}$ response of the full PCBL simulation is shown in black in Fig. 2b, and the responses are broken down into component mechanisms in Fig. 2c.

During the last interglacial, $\mathrm{CO}_{2}$ dynamics in the full experiment, PCBL, increases from an initial value of $280 \mathrm{ppmv}$ at $125 \mathrm{kyr} \mathrm{BP}$ to $285 \mathrm{ppmv}$ at $118 \mathrm{kyr} \mathrm{BP}$ (Fig. 2b). This is driven by the response of the terrestrial biosphere to climate trends during the late interglacial, as the drying of the northern subtropical regions and the southward retreat of boreal forests decrease land carbon storage by about $300 \mathrm{GtC}$ during this period (Fig. 3). In the $\mathrm{P}$ simulation, the increased $\mathrm{CO}_{2}$ solubility in seawater due to lowered SSTs leads to an atmospheric $\mathrm{CO}_{2}$ decrease during the late interglacial, while carbonate chemistry processes, including the accumulation of shallow-water carbonates, force $\mathrm{CO}_{2}$ in the opposite direction leading to $\mathrm{CO}_{2}$ stagnation till $117 \mathrm{kyr} B P$ in the $\mathrm{PC}$ and PCB simulations (Fig. 2c).

The glacial inception results in an abrupt $\mathrm{CO}_{2}$ drop by ca. $50 \mathrm{ppmv}$ to the level of 230-235 ppmv (Fig. 2b) by $110 \mathrm{kyr} \mathrm{BP}$, which is in a good agreement with the Vostok ice core data (Barnola et al., 1987). The main mechanism here is physical (simulation P). It is the reduction in the SSTs and the substitution of North Atlantic Deep Water by colder and saltier waters of Antarctic origin that lead to a drop of ca. 30 ppmv (Brovkin et al., 2007). The essence of the later 
mechanism, called the "standing volume effect" (Skinner, 2009), is that the dissolved inorganic carbon (DIC) content of southern-source water is higher than that of North Atlantic deep water, leading to increased DIC storage in the deep ocean. The model during glacial inception simulates a decrease in $\delta^{13} \mathrm{C}$ in deep tropical Atlantic by $0.2 \%$ qualitatively in agreement with the benthic $\delta^{13} \mathrm{C}$ data (Lisiecki et al., 2008; Oliver et al., 2010) (Fig. 2d).

During the rest of the glacial period, physical mechanisms only have a substantial impact on atmospheric $\mathrm{CO}_{2}$ during Heinrich and Dansgaard-Oeschger type events, when the Atlantic meridional overturning circulation (AMOC) is greatly perturbed (Fig. 2a). During these events, the model produces spikes of $\mathrm{CO}_{2}$ of about 10 ppmv (Fig. 2c) due to outgassing of oceanic $\mathrm{CO}_{2}$, mostly via the Southern Ocean (Anderson et al., 2009). At the same time, the deep ocean is enriched in negative $\delta^{13} \mathrm{C}$ due to increased water mass ages (Fig. $2 \mathrm{~d}$ and e). Millennial-scale variability in atmospheric $\mathrm{CO}_{2}$ during abrupt changes in AMOC is visible in the high-resolution Byrd ice core data (Ahn and Brook, 2008). The specific timings of the abrupt climate events are different from the observed ones as they depend on freshwater discharge into the North Atlantic, which are random output resulting from the instability of the Laurentide ice sheet within the model.

By $110 \mathrm{kyr} \mathrm{BP}$, carbonate compensation amplifies the physically driven changes in atmospheric $\mathrm{CO}_{2}$ by an additional 10 ppmv (Fig. 2c, the difference between $\mathrm{P}$ and $\mathrm{PC})$. Between 110 and $100 \mathrm{kyr} \mathrm{BP}$, atmospheric $\mathrm{CO}_{2}$ rises by $20 \mathrm{ppmv}$ as a consequence of partial deglaciation due to increasing summer insolation in boreal region (Fig. 1d). This $\mathrm{CO}_{2}$ response to the precessional cycle is not evident in the ice core data (Barnola et al., 1987), although the coarse temporal resolution of the only available Vostok record that might be insufficient for resolving the cycle. Between 90 and $70 \mathrm{kyr} \mathrm{BP}$, the model yields atmospheric $\mathrm{CO}_{2}$ concentrations at the level of 230-240 ppmv, in line with the Byrd ice-core record (Ahn and Brook, 2008). After $70 \mathrm{kyr} \mathrm{BP,} \mathrm{the} \mathrm{effect} \mathrm{of}$ fertilization of marine biological production in sub-Antarctic Atlantic ocean by aeolian dust leads to a $\mathrm{CO}_{2}$ drop to a level of 200-210 ppmv (Fig. 2c). The timing of the dust effect on the carbon cycle is in line with box model simulations (Hain et al., 2010; Martinez-Garcia et al., 2009; Ridgwell and Watson, 2002; Watson et al., 2000), although the magnitude of the impact of iron fertilization differs among models (e.g, Parekh et al., 2008). Enhanced marine productivity leads to an additional $\mathrm{CO}_{2}$ drop with minima of $p \mathrm{CO}_{2}$ at 63 and $20 \mathrm{kyr} \mathrm{BP}$ in simulations PCB and PCBL (Fig. 2c). These minima are also pronounced in the deep ocean $\delta^{13} \mathrm{C}$, both in the model and in the data (Fig. $2 \mathrm{~d}$ and e). During the remaining period of 60-20 kyr BP, modelled atmospheric $\mathrm{CO}_{2}$ stays in the range of 200-220 ppmv, with one exceptional spike at $54 \mathrm{kyr} \mathrm{BP}$ when $\mathrm{CO}_{2}$ quickly rises to $230 \mathrm{ppmv}$ during a Heinrich-type event and relaxes slowly to the level of 220 ppmv thereafter.
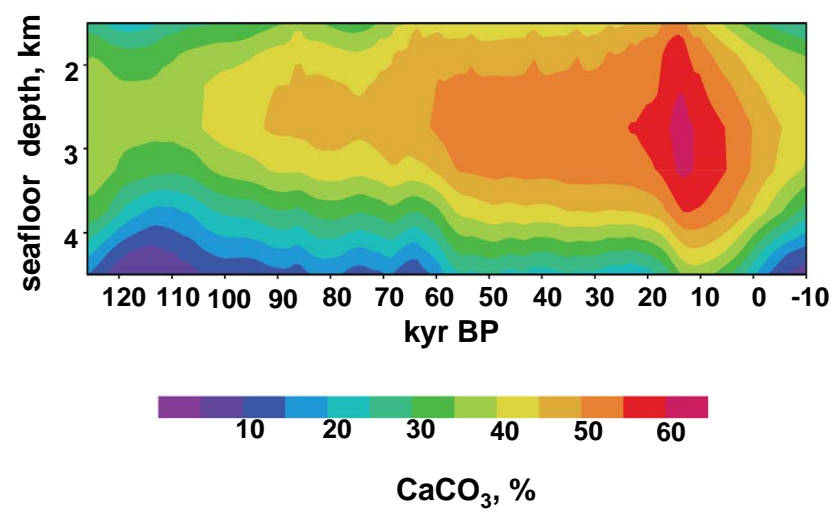

Fig. 4. Dynamics of the vertical distribution of the simulated $\mathrm{CaCO}_{3}$ fraction (\%) in top layer of seafloor sediments averaged over $30^{\circ} \mathrm{S}-30^{\circ} \mathrm{N}$ in the Pacific Ocean.

The model atmospheric $\mathrm{CO}_{2}$ concentration during the Last Glacial Maximum was about 200-210 ppmv, ca. 10 ppmv higher than in the EPICA Dome C (EDC) record (Monnin et al., 2004). In the equilibrium model simulation (Brovkin et al., 2007), the $\mathrm{CO}_{2}$ level was higher (about 220 ppmv). In equilibrium experiments, the total ocean alkalinity is implicitly prescribed by initial conditions; whereas in transient simulation, it is calculated interactively as a cumulative balance between weathering and sedimentation fluxes, which vary in time.

Deglaciation in the model starts by ca. $20 \mathrm{kyr}$ BP in line with the sea level data (Fig. 1d). The increased freshwater flux to the North Atlantic shuts down the AMOC (Fig. 2a). In response, atmospheric $\mathrm{CO}_{2}$ rises by about 10 ppmv (Fig. 2b). Between $18 \mathrm{kyrBP}$ and $11 \mathrm{kyr} \mathrm{BP}, \mathrm{CO}_{2}$ rises from about 200 to $235 \mathrm{ppmv}$, which is less than the steep increase in the EDC data by about 50 ppmv. A substantial part of the $\mathrm{CO}_{2}$ increase (ca. $20 \mathrm{ppmv}$ ) is due to reduced marine productivity in the sub-Antarctic region (Fig. 2c, PCB). After the AMOC recovers, the ocean circulation returns to an interglacial condition with enhanced North Atlantic Deep Water formation, interrupted by a short shutdown at $11 \mathrm{kyr} B$ P.

In the PCBL simulation, accumulation of $\mathrm{CaCO}_{3}$ in the deep tropical Pacific decreases during both the last interglacial (126-115 kyr BP) and the Holocene in response to enhanced shallow-water $\mathrm{CaCO}_{3}$ burial on shelves (Fig. 4). During the glacial period, $\mathrm{CaCO}_{3}$ burial increased, with a peak of preservation during deglaciation at about $15 \mathrm{kyr} \mathrm{BP}$, in line with data from the deep South Atlantic (Hodell et al., 2001; Anderson et al., 2008). A key diagnostic of ocean carbonate chemistry, the concentration of carbonate ion, $\left[\mathrm{CO}_{3}^{2-}\right]$, changes in the deep ocean through the glacial cycle. At the LGM, $\left[\mathrm{CO}_{3}^{2-}\right]$ increases by $10-15 \mu \mathrm{mol} \mathrm{kg}{ }^{-1}$ in the deep tropical Pacific and peaks during deglaciation as ocean $\mathrm{CO}_{2}$ is released into the atmosphere (Yu et al., 2010) (Fig. 5). In the deep tropical Atlantic, $\left[\mathrm{CO}_{3}^{2-}\right]$ and $\mathrm{CaCO}_{3}$ burial decrease during interglacials, but carbonate preservation peaks 

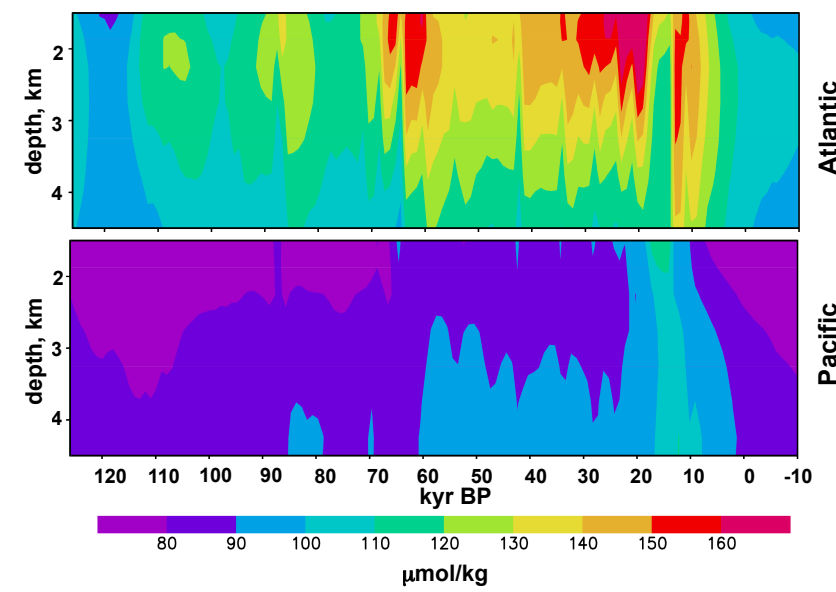

Fig. 5. Dynamics of the vertical distribution of simulated $\left[\mathrm{CO}_{3}^{2-}\right]$ concentration in the deep ocean (in $\mu \mathrm{mol} \mathrm{kg}{ }^{-1}$ ) averaged over $30^{\circ} \mathrm{S}-30^{\circ} \mathrm{N}$ : Atlantic Ocean (top panel); Pacific Ocean (bottom panel).

during LGM and the early Holocene. Contrary to the Pacific, $\left[\mathrm{CO}_{3}^{2-}\right]$ in the Atlantic decreases during deglaciation as a shutdown of the Atlantic meridional overturning circulation brings in Antarctic bottom waters characterized by lower $\left[\mathrm{CO}_{3}^{2-}\right]$. The resumption of circulation leads to an increase in $\left[\mathrm{CO}_{3}^{2-}\right]$ and enhanced preservation of $\mathrm{CaCO}_{3}$. The later maximum in $\mathrm{CaCO}_{3}$ preservation in the Atlantic is consistent with sedimentary data (Broecker et al., 2001; Hodell et al., 2001), as is the Atlantic maximum in $\left[\mathrm{CO}_{3}^{2-}\right]$ at the LGM (Rickaby et al., 2010). Let us note that the comparison of simulated and reconstructed changes in $\left[\mathrm{CO}_{3}^{2-}\right]$ for particular sites could be misleading, as it strongly depends on the spatial resolution of the model and interpretation of proxies used for reconstructions. As there is no global synthesis of reconstructed $\left[\mathrm{CO}_{3}^{2-}\right]$ available yet, comparison of simulated glacial carbonate ion concentration with data is currently beyond the scope of this paper.

The calcium carbonate preservation in the deep tropical Pacific and Atlantic for the pre-industrial (0 kyr BP) and the LGM $(18 \mathrm{kyr} B P)$ in the PCBL simulation is presented in Fig. 6. The model results are compared with the coretop $\mathrm{CaCO}_{3}$ preservation data from Catubig et al. (1998) averaged on the CLIMBER resolution. We limit our comparison to depths below $2 \mathrm{~km}$ because in the dataset of Catubig et al. (1998) only few cores are available for shallower depths in the $30^{\circ} \mathrm{S}-30^{\circ} \mathrm{N}$ latitude band. For the pre-industrial, the model captures observed difference in $\mathrm{CaCO}_{3}$ preservation between the deep Pacific and the deep Atlantic well. Both data and model show stronger dissolution of sediments in equatorial Pacific below $3 \mathrm{~km}$ (Fig. 6, left panel) and a deeper maximum of $\mathrm{CaCO}_{3}$ preservation in Atlantic (Fig. 6, right panel). For the LGM, the model simulates higher $\mathrm{CaCO}_{3}$ preservation in deep Pacific, which is less pronounced than

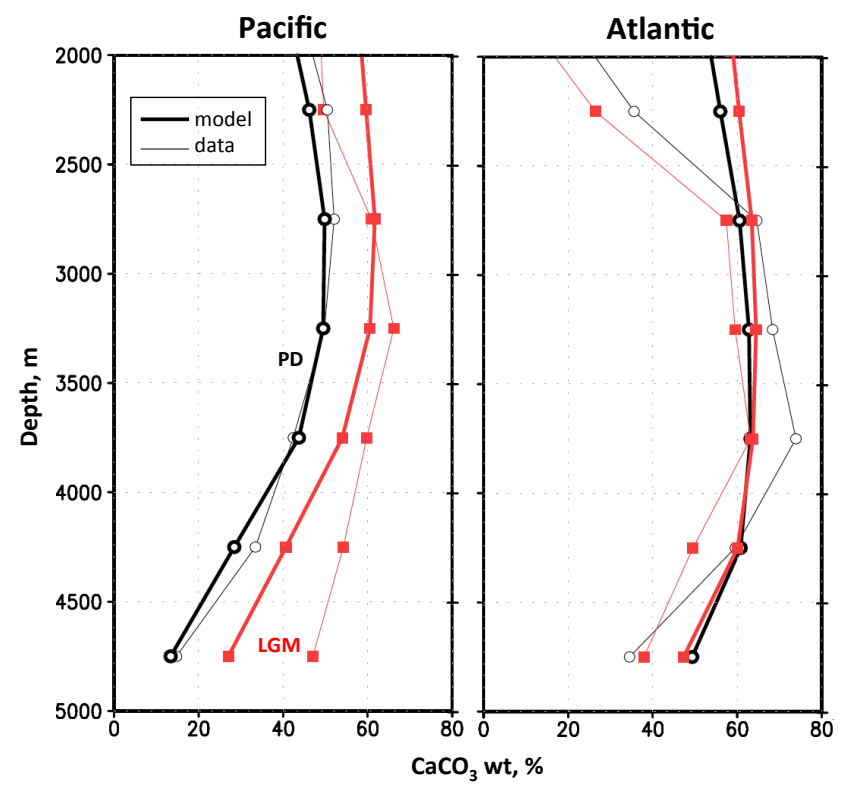

Fig. 6. Vertical distribution of the $\mathrm{CaCO}_{3}$ fraction (\%) in the top layer of seafloor sediments averaged over $30^{\circ} \mathrm{S}-30^{\circ} \mathrm{N}$, Pacific (left panel) and Atlantic Ocean (right panel). Thick lines are results of the PCBL simulation and thin lines are for the coretop $\mathrm{CaCO}_{3}$ preservation data from Catubig et al. (1998) averaged on the CLIMBER resolution. Black lines and open circles are for preindustrial (PI, 0 kyr BP), red lines and closed squares are for the LGM (18 kyr BP).

in the data for depths below $3 \mathrm{~km}$ (Fig. 6, left panel). In the tropical Atlantic, data for the LGM reveals increased dissolution at almost all depths. The model simulates a small decrease in $\% \mathrm{CaCO}_{3}$ below $4 \mathrm{~km}$ depth and a small increase above this depth (Fig. 6, right panel). Although the model does not capture well the relative changes in $\mathrm{CaCO}_{3}$ dissolution between the LGM and the pre-industrial in tropical Atlantic, it does reproduce a different response of carbonate preservation in the deep Atlantic and Pacific to glacial conditions.

The main forcing of atmospheric $\mathrm{CO}_{2}$ after $10 \mathrm{kyr} \mathrm{BP}$ is a reduction of ocean alkalinity resulting from coral reef regrowth (Kleypas, 1997) and its impact on the $\mathrm{CaCO}_{3}$ cycle (Ridgwell et al., 2003). The terrestrial biosphere ameliorates the $\mathrm{CO}_{2}$ rise by taking about $500 \mathrm{GtC}$ in between 18 and $5 \mathrm{kyr}$ BP (Fig. 3) in response to changes in climate, atmospheric $\mathrm{CO}_{2}$ concentration, and sea level rise. By $0 \mathrm{kyr} B P$, the carbonate chemistry is still not fully equilibrated to interglacial conditions, as atmospheric $\mathrm{CO}_{2}$, now at $274 \mathrm{ppmv}$, continues to rise. Extending the model runs by $10 \mathrm{kyr}$ into the future (without anthropogenic perturbations) allows the model to find an interglacial equilibrium of $279 \mathrm{ppm}$ at $4 \mathrm{kyr}$ in the future. The main difference between this state and the previous interglacial state at $126 \mathrm{kyr}$ is that the terrestrial biosphere carbon storage is about $250 \mathrm{GtC}$ smaller, due to more favourable conditions of the past interglacial relative to 


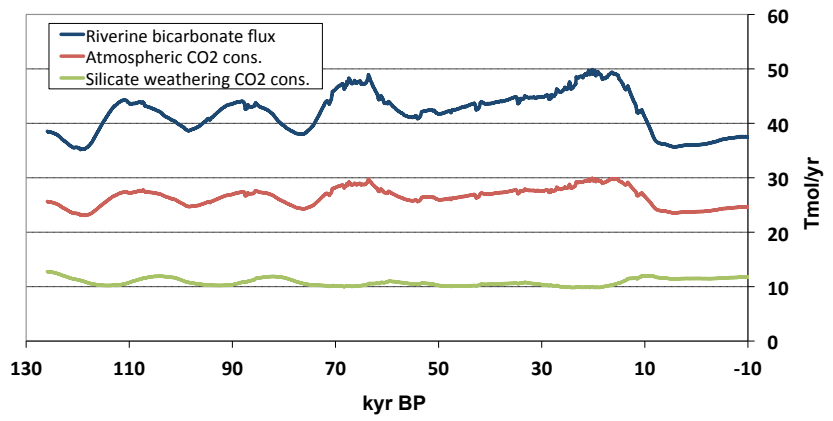

Fig. 7. Dynamics of the riverine bicarbonate flux (blue), the global atmospheric $\mathrm{CO}_{2}$ consumption rate (brown) and silicate weathering $\mathrm{CO}_{2}$ consumption rate (green) in the PCBL simulation (in $T_{\mathrm{mol} \mathrm{yr}}{ }^{-1}$ ).

the Holocene (Fig. 3). Recent evidence (Zimov et al., 2009) suggests that several hundred GtC might have been stored in the high latitude regions in permafrost soils during the glacial period. Therefore, although model experiments suggest that the land biosphere had 500-800 Gt less carbon at the LGM than during the Holocene (Kaplan et al., 2002), the simulated reduction in glacial land carbon storage could possibly be overestimated since these models neglect changes in permafrost carbon storage.

A substantial part of the glacial-interglacial changes in the carbonate chemistry in the PC, PCB, and PCBL simulations is due to the changes in the continental weathering (Fig. 7). The global riverine bicarbonate $\left(\mathrm{HCO}_{3}^{-}\right)$flux increases from 36-38 $T_{\mathrm{mol}} \mathrm{yr}^{-1}$ in interglacial states to almost $50 T_{\mathrm{mo}} \mathrm{yr}^{-1}$ in the LGM. Changes in the $\mathrm{HCO}_{3}^{-}$flux result from changes in the runoff distribution (globally reduced during glacial periods) and in the area of exposed continental shelves (increased during glacials). The relevant parts of the latter are mainly located in the tropical regions where shelves are mainly covered with carbonates. The main increase in the global weathering during glacials comes from carbonate weathering, as documented by the atmospheric $\mathrm{CO}_{2}$ consumption rates depicted in Fig. 7. The increase in carbonate weathering is reflected by the difference between the global $\mathrm{CO}_{2}$ consumption and silicate weathering, or, equivalently, between the global river $\mathrm{HCO}_{3}^{-}$flux and the global $\mathrm{CO}_{2}$ consumption. The change in the $\mathrm{CO}_{2}$ consumption rate due to silicate weathering is less pronounced. It varies between 12

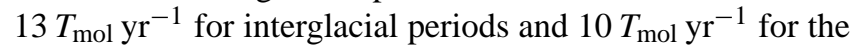
last glacial maximum (Fig. 7). Silicate weathering varies out of phase with total $\mathrm{CO}_{2}$ consumption and $\mathrm{HCO}_{3}^{-}$production rates (both dominated by carbonate weathering variations). This is because carbonate weathering variations are mainly driven by the shelf exposure mainly located in the tropics, while silicate weathering fluxes are related to the expansion and retreat of the ice-sheets as well as the runoff change over the continental areas that remain exposed throughout the entire simulation. (a) Northern water masses in Atlantic

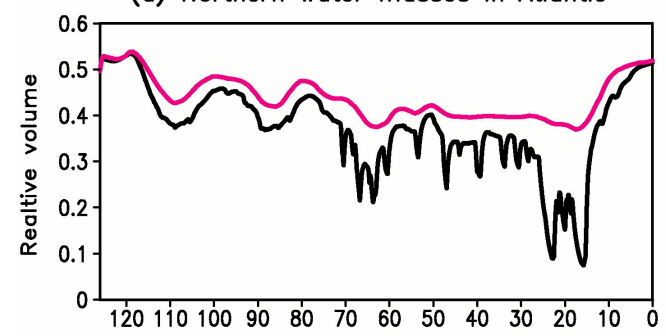

(c) $\mathrm{CO} 2$

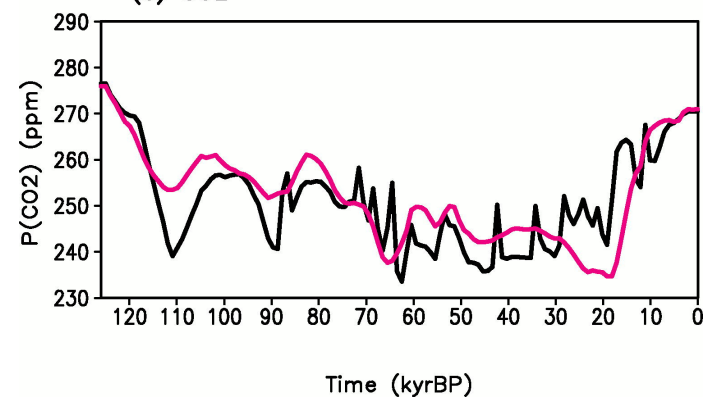

Fig. 8. Relative volume of the water masses of the northern origin in the Atlantic ocean (a) and simulated atmospheric $\mathrm{CO}_{2}$ concentration (b). Black line - experiment $P$, pink line - experiment P_NOI.

\section{2 "Standing volume" effect on the atmospheric $\mathrm{CO}_{2}$ concentration}

For a better understanding of the physical mechanisms responsible for the glacial $\mathrm{CO}_{2}$ drawdown, it is useful to compare the standard experiment $\mathrm{P}$, which only includes physical processes, with an even more schematic experiment P_NOI. In that experiment the ice sheet component was switched off and therefore neither climate changes due to growth and decay of the ice sheets nor variations in the sea level and ocean volume affect the carbon cycle. Therefore, all climate changes that affect the carbon cycle in this experiment are only driven by orbital forcing and radiative forcing of the changing $\mathrm{CO}_{2}$ concentration. Note that the direct effect of orbital forcing on climate and $\mathrm{CO}_{2}$ is rather small. In all other respects, the experiment $\mathrm{P} \_\mathrm{NOI}$ is equivalent to the experiment P. Simulated $\mathrm{CO}_{2}$ variations for the $\mathrm{P}$ and $\mathrm{P} \_\mathrm{NOI}$ simulations are shown in Fig. 8 by black and pink lines, respectively. The simulated atmospheric $p \mathrm{CO}_{2}$ in the P_NOI experiment closely resembles the prescribed equivalent $\mathrm{CO}_{2}$ concentration but with about a three times smaller amplitude of variation (Fig. 8). The maximum glacial/interglacial $\mathrm{CO}_{2}$ difference in this experiment is about $40 \mathrm{ppm}$. Since variations in the global mean SST are about $2{ }^{\circ} \mathrm{C}$ (similar changes are simulated in the global surface air temperature and the deep ocean temperatures), this implies a $\mathrm{CO}_{2}$ sensitivity to temperature changes of about $20 \mathrm{ppm}^{\circ} \mathrm{C}^{-1}$, which is too high for the solubility effect alone (Archer et al., 2004). In fact, the solubility effect explains only ca. $10 \mathrm{ppm}$, while 
the rest results from changes in the redistribution of major water masses and their ventilation.

The first effect is now commonly known as the "standing volume effect" (Skinner, 2006, 2009). This effect was already discerned in previous equilibrium glacial CLIMBER-2 simulations (Brovkin et al., 2007). The essence of this effect is that under glacial climate conditions, the volume of the water masses in the World Ocean originating from the North Atlantic decreases and the volume of the water masses forming in the SO increases. Since the DIC concentration is higher in the water masses originating in the SO than in NADW, this leads to an increase of carbon storage in the deep ocean. To illustrate this effect we have added a dye tracer to the ocean which allows us to compute the relative contributions of the water masses of each origin at any location. Figure 9 shows that in the interglacial climate state, most of the deep Atlantic is filled with water masses originating in the North Atlantic. Under glacial climate conditions, the upper cell of the AMOC becomes shallower and more water masses of southern origin penetrate into the deep Atlantic. As a result, the fraction of the northern water masses in the deep Atlantic decreases from almost $100 \%$ to $50 \%$. Smaller but non negligible changes were also found in the Pacific and Indian oceans (not shown). Note that the increase of the fraction of the water masses of southern origin is not related to the changes in the rate of Antarctic bottom water (AABW) formation but to a relative increase in the density of AABW compared to NADW. This, in turn, is primarily related to the enhanced sea ice formation in the Southern Ocean, stronger brine rejection and an increase of the AABW salinity (Brovkin et al., 2007). Increased salinity of AABW qualitatively agrees with empirical reconstructions (Adkins et al., 2002). Since glacial/interglacial climate change in the Southern Ocean is primarily explained by changes of GHG concentrations, the increase of the sea ice area in the P_NOI experiment is similar to that in the $\mathrm{P}$ experiment with the interactive ice sheets. As a result, the fraction of northern water masses in the World Ocean (below $1.5 \mathrm{~km}$ ) in the P_NOI experiment decreases at the LGM by ca. $10 \%$ compared to the interglacial state. During the first $100 \mathrm{ka}$, the changes in the fraction of the North Atlantic water masses are similar in the $\mathrm{P}$ and in the P_NOI experiments, but around the LGM, the fraction of water masses originated in the North Atlantic falls drastically in the $\mathrm{P}$ experiment, which is related to further weakening and frequent shutdowns of the AMOC at this period. This further reduction in the fraction of North Atlantic water masses, however, does not result in any further $\mathrm{CO}_{2}$ drop. In fact, the $\mathrm{CO}_{2}$ concentration at this period of time in the P_NOI experiment is even lower than in the P simulation. This can be explained by the fact that the weakening of the AMOC in the $\mathrm{P}$ experiment results in a reduction of the $\mathrm{CO}_{2}$ uptake in the North Atlantic, which in turn leads to a decrease of DIC in the intermediate water masses and compensates for the increase in the fraction of the water masses of southern origin.
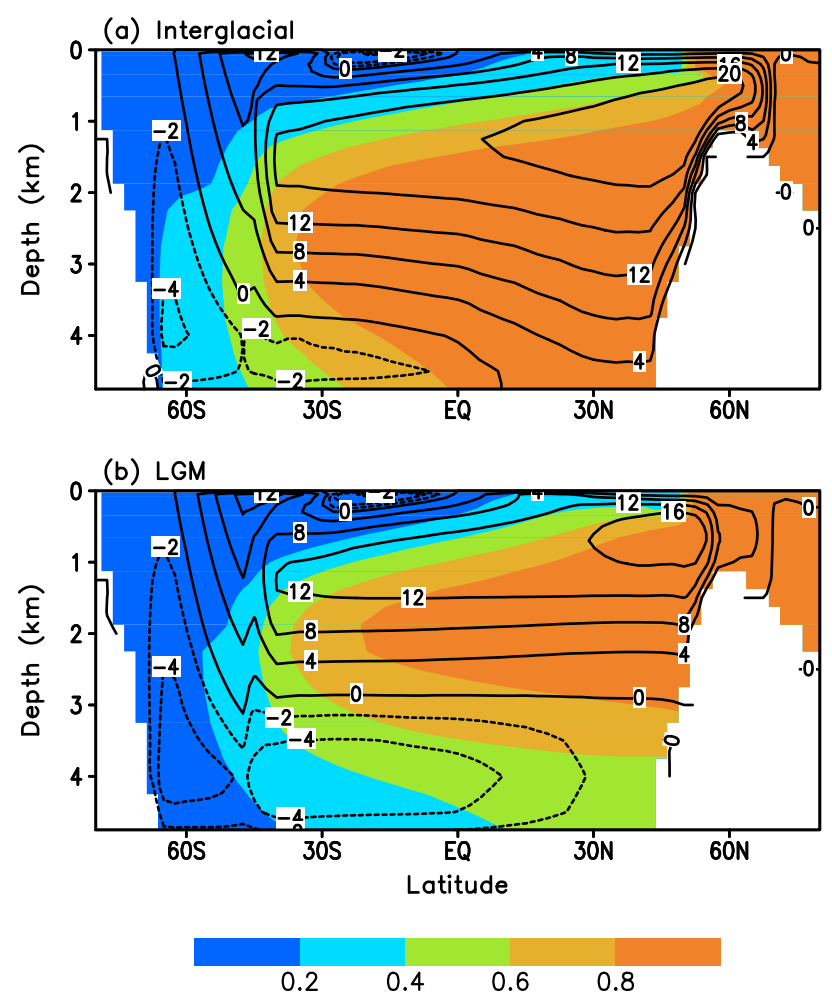

Fig. 9. "Dye" tracer concentration (shading) and meridional overturning circulation (in Sv, contours) in the Atlantic for interglacial (a) and LGM (b) states. Northern water masses have a "dye" concentration of 1 and the southern water masses of 0 .

Recently, Bouttes et al. (2011a) used another version of CLIMBER-2 model to analyse equilibrium sensitivity of the glacial carbon cycle to brine-induced stratification, stratification-dependant diffusion, and iron fertilization. They demonstrated that, with certain parameterizations of these processes, the model is able to reproduce the atmospheric $\mathrm{CO}_{2}$ level and the ocean carbon isotopic composition observed for the LGM. The results of Bouttes et al. (2011a) can possibly be interpreted in terms of the "standing volume effect". However, such an analysis would require additional experiments which go beyond the purpose of this study.

Changes in the "standing volume" also have an effect on the oxygen content of the intermediate and deep waters in the tropical Pacific (Fig. 10). In the interglacial states, these waters are well ventilated (Fig. 10, top panel). During the glacial state, the oxygen concentration declines as a result of the increased fraction of waters originating in the SO, the decrease of Southern water ventilation and the slowdown of the circulation in the Pacific basin. This effect is slightly more pronounced in the case where we take the enhancement by the marine biology into account (PCBL simulation, see Fig. 10, bottom panel). The large-scale anoxia in the tropical Pacific during glacial states is not supported by paleoproxies, although there are data that suggest that the bulk of 


\section{Oxygen content, tropical Pacific}

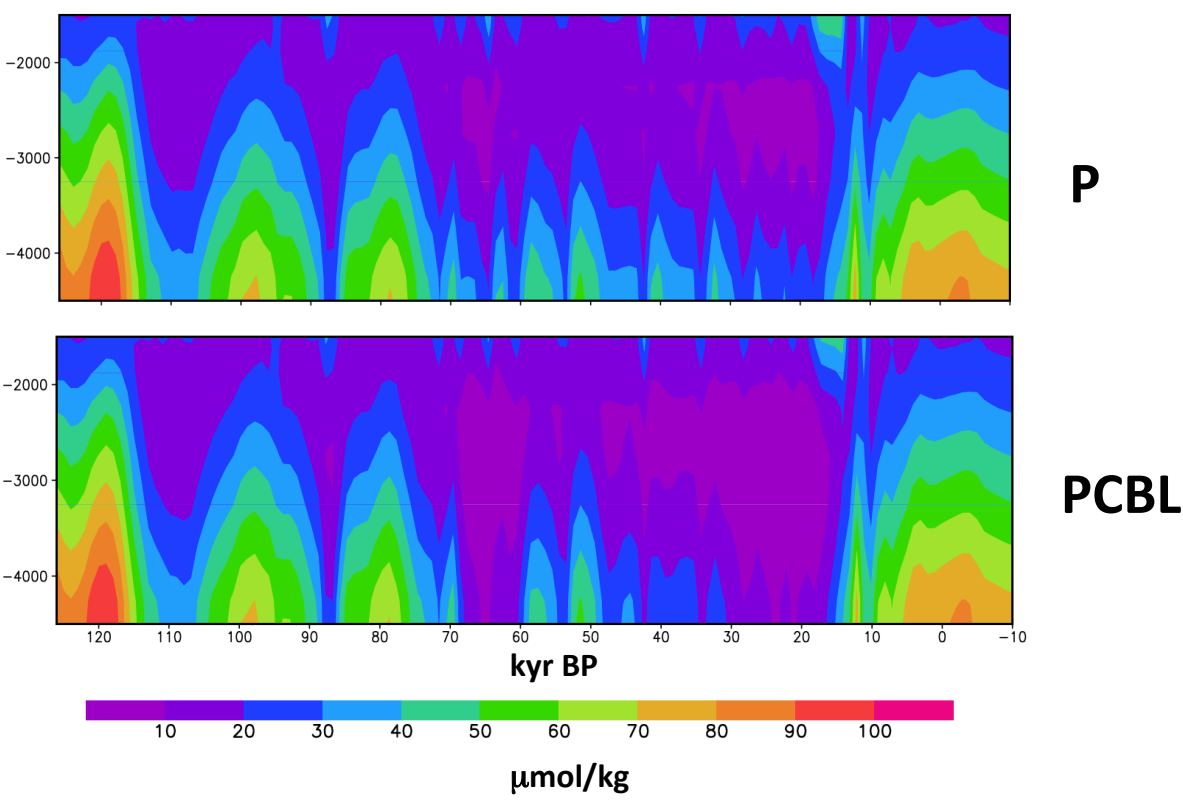

Fig. 10. Dynamics of the vertical distribution of the simulated $\mathrm{O}_{2}$ concentration $(\mu \mathrm{mol} \mathrm{kg}-1)$ averaged over $30^{\circ} \mathrm{S}-30^{\circ} \mathrm{N}$ in the Pacific Ocean.

the deep ocean was less oxygenated during the LGM (Jaccard and Galbraith, 2012). It is important to note that oxygen concentration simulated in the model deep Pacific for the preindustrial is about two times less than observed. Therefore, we think that simulated trends are more reliable than the absolute values for the oxygen content and that the simulated lowering of oxygen content during glacial times is not necessarily in contradiction with the available data. Relative to $\mathrm{Pa}$ cific, the oxygen content in the Atlantic basin is much higher throughout the simulations. A considerable reduction in the oxygen content (but still well above anoxia level) in the tropical Atlantic is simulated only during periods of a shutdown of the AMOC. The oxygen content restores rapidly after the circulation recovers (not shown).

\subsection{Millennial-scale variability in atmospheric $\mathrm{CO}_{2}$}

Apart from climate changes on the orbital time scales, the CLIMBER-2 model simulates pronounced millennial scale variability associated with changes in the AMOC strength caused by the changing freshwater flux into the northern North Atlantic (Fig. 2a). The largest fluctuations of the freshwater flux are associated with the internal instability of the Laurentide ice sheet and the development of fast ice streams over the Hudson Strait (Calov et al., 2002). These events of enhanced ice flux resemble real Heinrich events and result in additional freshwater fluxes of about $0.1 \mathrm{~Sv}$ during several hundreds to one thousand years. Since Heinrich-like events simulated in the model result from internal instability of the ice sheet component, their timing is random and does not coincide with the timing of real Heinrich events. During these intervals of enhanced freshwater flux into the North Atlantic, the AMOC weakens considerably. The NADW formation area retreats southward and the AMOC cell shoals (Ganopolski and Rahmstorf, 2001). These changes of the AMOC are closely associated with millennial scale variations in the atmospheric $\mathrm{CO}_{2}$ concentration (Fig. 2b and c). During the phases of weak AMOC, the $\mathrm{CO}_{2}$ concentration rises rapidly by $10-20 \mathrm{ppm}$ and equally rapidly drops after the resumption of strong AMOC. The temporal dynamics and the magnitude of the simulated millennial $\mathrm{CO}_{2}$ variations resemble $\mathrm{CO}_{2}$ variations in the Byrd ice core record during Heinrich stadials (Fig. 2b).

The strong positive excursions in the $\mathrm{CO}_{2}$ concentration during Heinrich-like events can already be seen in the P experiment. The magnitude of these variations is essentially the same in the experiment with and without terrestrial biosphere. Therefore, the rise of $\mathrm{CO}_{2}$ concentration during the weak AMOC in our model can be primarily attributed to the ocean component of the carbon cycle. The small contribution of the terrestrial biosphere to the $\mathrm{CO}_{2}$ change can be explained by the absence of terrestrial vegetation in the areas primarily affected by the reorganization of the AMOC under the glacial climate conditions. The detailed analysis of the mechanisms behind the millennial scale variability of the atmospheric $\mathrm{CO}_{2}$ concentration reveals considerable complexity and a number of counteracting mechanisms involved. 
During periods of weakened AMOC, the carbon uptake in the northern North Atlantic is significantly reduced and DIC in the core of NADW decreases. However, a reduction of the carbon content in the upper part of the Atlantic is compensated by an increase of DIC in the deep Atlantic due to the substitution of NADW by water masses of southern origin which have relatively high DIC concentration. As a result, the Atlantic Ocean, although characterized by the largest changes in the atmosphere-ocean carbon fluxes, does not contribute much to the $\mathrm{CO}_{2}$ rise during stadials. In the Southern Ocean, neither the surface fluxes nor the total carbon inventory are appreciably affected by changes in the AMOC in spite of significant variations in the surface temperature and sea ice cover caused by the reduction of the northward ocean heat flux (i.e. the "bipolar seesaw" mechanism). This is because the increase of the oceanic outgassing in the area where the southern sea ice cover is retreated polarwards is counteracted by an increase in the strength of the biological pump.

There are little changes in the surface ocean-atmosphere carbon fluxes over the Indo-Pacific but the carbon inventory indicates that the rise of the atmospheric $\mathrm{CO}_{2}$ during periods of weakened AMOC is explained by the loss of carbon from the Indo-Pacific. The decrease in DIC occurs here primarily between 1 and $3 \mathrm{~km}$ depth and can be explained by a weakening of the reverse cell of the Indo-Pacific overturning circulation during periods of reduced AMOC. This leads to a reduction of the vertical nutrient transport and, as a result, to a weakening of the biological carbon pump. This mechanism is consistent with the results of Schmittner (2005) who found similar changes in the overturning circulation, nutrient distribution and primary production in the Indo-Pacific. Therefore, the mechanisms of the millennial and of the orbital scale variability of the atmospheric $\mathrm{CO}_{2}$ in our model are fundamentally different.

Previous studies of the carbon cycle response to a weakening or a complete shutdown of the AMOC produced controversial results. While Marchal et al. (1999), Schmittner and Galbraith (2008), Chikamoto et al. (2008) and Bouttes et al. (2011b) found that the ocean was releasing $\mathrm{CO}_{2}$ during weakenings of the AMOC, Obata (2007), Menviel et al. (2008) and Bozbiyik et al. (2011) reported opposite results. We conclude that the complexity of the response of atmospheric $p \mathrm{CO}_{2}$ to such changes in the AMOC and a number of counteracting processes taken into account in our model may explain why this response is so strongly model-dependent.

\section{Conclusions}

According to our results, physical mechanisms - reduction in SSTs and changes in standing volume in response to the expansion of ice-sheets, especially in the Northern Hemisphere, and the resulting lower sea level - lead to the initial drop of $\mathrm{CO}_{2}$ during a glacial inception. This drop, amplified by the $\mathrm{CaCO}_{3}$ cycle, is followed by an increased buildup of ocean alkalinity during the rest of the glacial cycle, as exposed tropical shelves serve as a source of $\mathrm{CaCO}_{3}$ to the ocean, and $\mathrm{CaCO}_{3}$ burial is shifted from shallow waters to the deep sea. Increased nutrient utilization in the sub-Antarctic plays the dominant role in further $\mathrm{CO}_{2}$ decline. The role of the land carbon is less certain, as recently published data suggest globally smaller changes in the land carbon storage between glacial and interglacial times than previously thought.

In the second part of the glacial cycle, our model simulates millennial scale variations in the atmospheric $\mathrm{CO}_{2}$ concentration that appear to be closely associated with AMOC changes. In response to AMOC weakenings, the $\mathrm{CO}_{2}$ concentration rapidly rises, similarly to $\mathrm{CO}_{2}$ variations observed during Heinrich stadials (Ahn and Brook, 2008). During these variations, the Indo-Pacific Ocean serves as a source of $\mathrm{CO}_{2}$, while the land carbon storage increases in response to the elevated $\mathrm{CO}_{2}$ concentration. Distributions of carbon sinks and sources in response to glacial AMOC changes differ among models due to counteracting effects of physical and biogeochemical mechanisms. A detailed analysis of the carbon cycle response to AMOC changes is certainly an interesting topic for future model intercomparison exercises.

During the deglaciation and the Holocene, the model simulates an increase in the atmospheric $\mathrm{CO}_{2}$ concentration that is of the right amplitude but less abrupt than the rapid $\mathrm{CO}_{2}$ rise recorded in the ice cores (Monnin et al., 2004). This mismatch could be due to limitations in the representation of ocean biogeochemistry, especially carbonate chemistry, in our zonally averaged model or to abrupt processes not considered in our land carbon model, such as rapid thawing of frozen organic matter stored in permafrost soils. Implementation of permafrost carbon could possibly also improve the $\mathrm{CO}_{2}$ dynamics during glacial inception. Constraining the amplitude of such a permafrost carbon feedback from paleo simulations is essential for projecting the response of the carbon cycle at high latitudes to anthropogenic climate change over the next centuries (Schaefer et al., 2011).

In this study, we did not consider the feedback from simulated atmospheric $\mathrm{CO}_{2}$ to the physical climate model. This partial decoupling between climate and carbon cycle is necessary to evaluate a role of different mechanisms in the glacial $\mathrm{CO}_{2}$ changes within the model framework. These numerical experiments serve as a basis for further simulations of glacial cycles driven solely by changes in orbital forcing. 

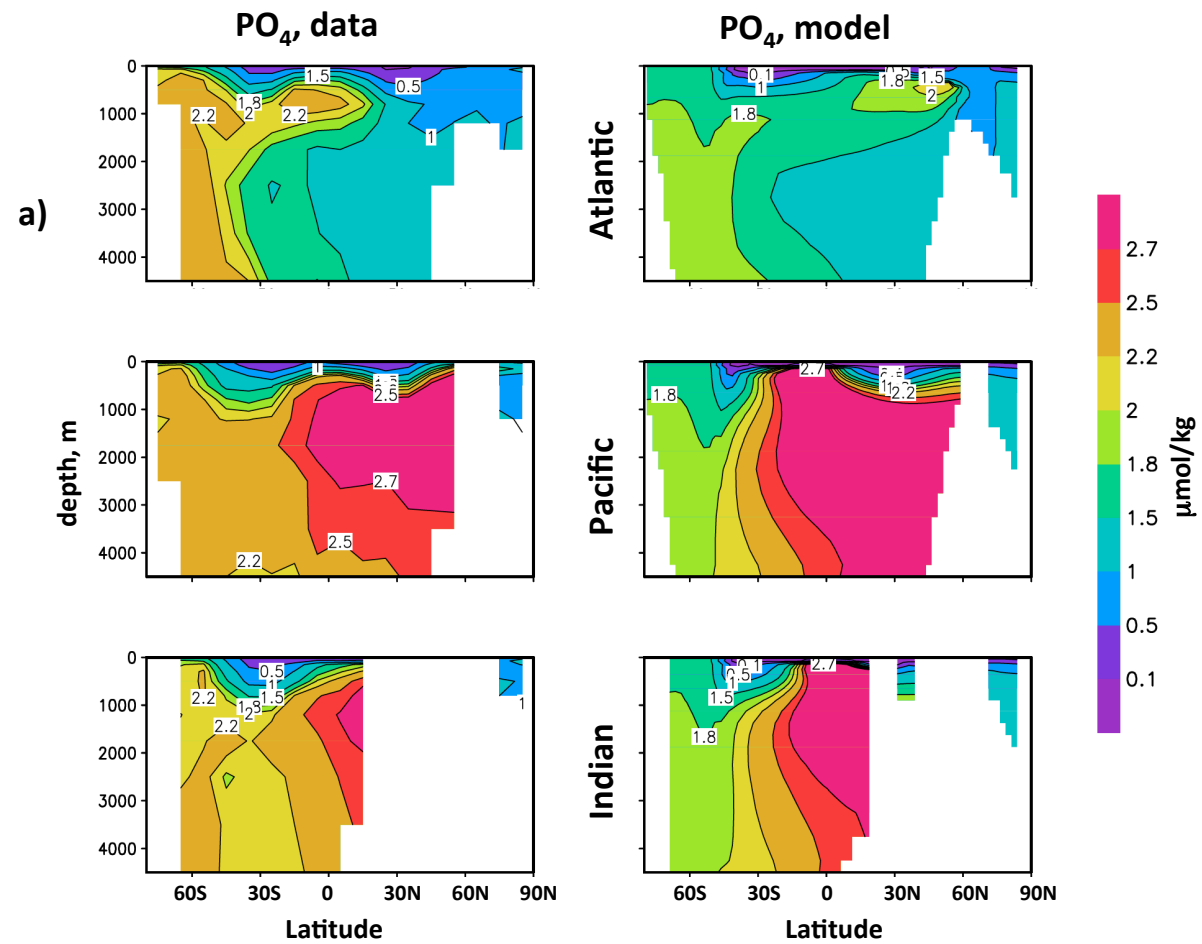

Fig. A1. Distribution of the biogeochemical tracers in the oceanic basins: (a) $\mathrm{PO}_{4}, \mu \mathrm{mol} \mathrm{kg}-1$; (b) dissolved organic carbon (DIC), $\mu \mathrm{mol} \mathrm{kg}-1$; (c) total alkalinity, (ALK), $\mu \mathrm{eq} \mathrm{kg}-1$; (d) ${ }^{14} \mathrm{C}(\%)$. Left panel: GEOSECS data zonally averaged and interpolated onto the model grid; right panel: equilibrium model simulation for pre-industrial conditions.

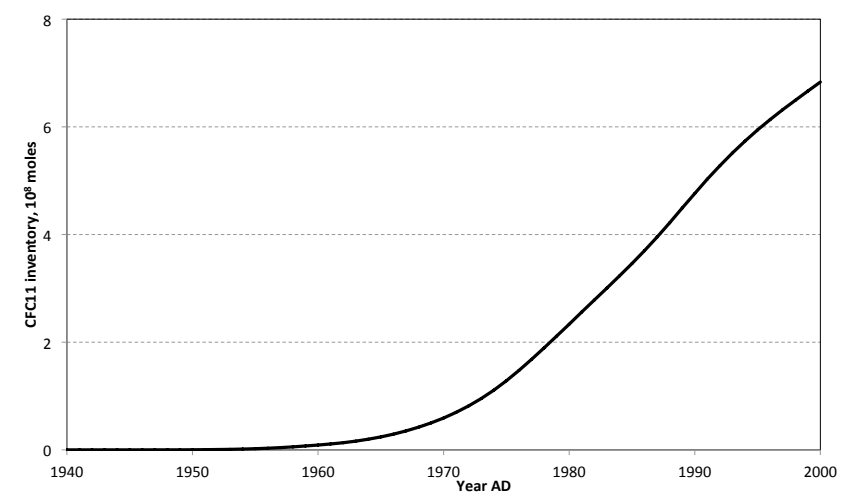

Fig. A2. Simulated oceanic inventory of CFC-11 ( $10^{8}$ moles $)$ in the 20th century.

\section{Appendix A}

\section{Evaluation of the ocean carbon cycle model}

\section{A1 Equilibrium pre-industrial simulation}

Simulated fields of essential biogeochemical tracers $\left(\mathrm{PO}_{4}\right.$, dissolved inorganic carbon, alkalinity, and ${ }^{14} \mathrm{C}$ ) from 4000 -yr equilibrium simulation of the model in the pre-industrial setup with orbital parameters and ice sheets of present day,

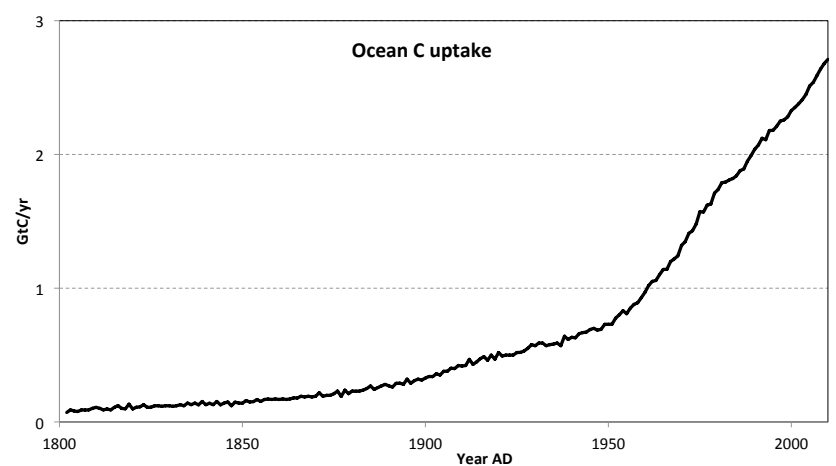

Fig. A3. Simulated oceanic carbon uptake $\left(\mathrm{GtC} \mathrm{yr}^{-1}\right)$ for the period 1800-2010.

and atmospheric $\mathrm{CO}_{2}$ concentration of 280 ppmv are presented in Fig. A1. For comparison, the left side of Fig. A1 presents present-day observations (GEOSECS) zonally averaged and interpolated onto the model grid. In general, the performance of the oceanic biogeochemistry model is very similar to the previously published versions (Brovkin et al., 2002, 2007). The current version tends to simulate older waters in the deep Northern Pacific and to accumulate more $\mathrm{PO}_{4}$ in the North Pacific. 


\section{A2 Transient simulations}

Ocean uptake of CFC-11 was computed following the OCMIP-2 protocol (Dutay et al., 2002). The simulated global uptake (Fig. A2) is within the range of OCMIP-2 models and in excellent agreement with the empirical estimate by Willey et al. (2004) (modeled $5.7 \times 10^{8}$ moles versus estimated $5.5( \pm 1.2) \times 10^{8}$ moles through the year 1994).

The ocean carbon uptake from the year 1800 to 1994 with a prescribed history for the concentration of $\mathrm{CO}_{2}$ in the atmosphere is $106 \mathrm{GtC}$. This is lower than the estimate of $118 \mathrm{GtC}$ from Sabine et al. (2004), but within the range of uncertainty of $\pm 19 \mathrm{GtC}$. The average carbon uptake in the $1990 \mathrm{~s}$ is $2.2 \mathrm{GtC} \mathrm{yr}^{-1}$, which is fully in agreement with the IPCC AR4 estimate of $2.2 \pm 0.4 \mathrm{GtC} \mathrm{yr}^{-1}$ (Denman et al., 2007). In the decade from 2000 to 2009 , the average uptake rises to $2.5 \mathrm{GtC} \mathrm{yr}^{-1}$ (Fig. A3).

Acknowledgements. The authors are very grateful to Andy Ridgwell and one anonymous reviewer for their helpful and constructive comments. G. Munhoven is a Research Associate with the Belgian Fund for Scientific Research FNRS.

The service charges for this open access publication have been covered by the Max Planck Society.

Edited by: L. Skinner

\section{References}

Adkins, J. F., McIntyre, K., and Schrag, D. P.: The salinity, temperature, and $\delta^{18} \mathrm{O}$ of the glacial deep ocean, Science, 298, 17691773, 2002.

Ahn, J., and Brook, E. J.: Atmospheric $\mathrm{CO}_{2}$ and climate on millennial time scales during the last glacial period, Science, 322, 83-85, doi:10.1126/science.1160832, 2008.

Amiotte-Suchet, P., Probst, J. L., and Ludwig, W.: Worldwide distribution of continental rock lithology: Implications for the atmospheric/soil $\mathrm{CO}_{2}$ uptake by continental weathering and alkalinity river transport to the oceans, Global Biogeochem. Cy., 17, 1038, doi:10.1029/2002gb001891, 2003.

Anderson, R. F., Fleisher, M. Q., Lao, Y., and Winckler, G.: Modern $\mathrm{CaCO}_{3}$ preservation in equatorial Pacific sediments in the context of late-Pleistocene glacial cycles, Mar. Chem., 111, 30-46, doi:10.1016/j.marchem.2007.11.011, 2008.

Anderson, R. F., Ali, S., Bradtmiller, L. I., Nielsen, S. H. H., Fleisher, M. Q., Anderson, B. E., and Burckle, L. H.: Wind-Driven Upwelling in the Southern Ocean and the Deglacial Rise in Atmospheric $\mathrm{CO}_{2}$, Science, 323, 1443-1448, doi:10.1126/science.1167441, 2009.

Archer, D.: A data-driven model of the global calcite lysocline, Global Biogeochem. Cy., 10, 511-526, 1996.

Archer, D., Winguth, A., Lea, D., and Mahowald, N.: What caused the glacial/interglacial atmospheric $p \mathrm{CO}_{2}$ cycles?, Rev. Geophys., 38, 159-189, 2000.
Archer, D., Martin, P., Buffett, B., Brovkin, V., Rahmstorf, S., and Ganopolski, A.: The importance of ocean temperature to global biogeochemistry, Earth Planet. Sc. Lett., 222, 333-348, doi:10.1016/j.epsl.2004.03.011, 2004.

Archer, D. E.: Modeling the calcite lysocline, J. Geophys. Res., 96, 17037-17050, 1991.

Archer, D. E., Martin, P. A., Milovich, J., Brovkin, V., Plattner, G. K., and Ashendel, C.: Model sensitivity in the effect of Antarctic sea ice and stratification on atmospheric $p \mathrm{CO}_{2}$, Paleoceanography, 18, 1012 ,doi:10.1029/2002pa000760, 2003.

Augustin, L., Barbante, C., Barnes, P. R. F., Barnola, J. M., Bigler, M., Castellano, E., Cattani, O., Chappellaz, J., DahlJensen, D., Delmonte, B., Dreyfus, G., Durand, G., Falourd, S., Fischer, H., Fluckiger, J., Hansson, M. E., Huybrechts, P., Jugie, R., Johnsen, S. J., Jouzel, J., Kaufmann, P., Kipfstuhl, J., Lambert, F., Lipenkov, V. Y., Littot, G. V. C., Longinelli, A., Lorrain, R., Maggi, V., Masson-Delmotte, V., Miller, H., Mulvaney, R., Oerlemans, J., Oerter, H., Orombelli, G., Parrenin, F., Peel, D. A., Petit, J. R., Raynaud, D., Ritz, C., Ruth, U., Schwander, J., Siegenthaler, U., Souchez, R., Stauffer, B., Steffensen, J. P., Stenni, B., Stocker, T. F., Tabacco, I. E., Udisti, R., van de Wal, R. S. W., van den Broeke, M., Weiss, J., Wilhelms, F., Winther, J. G., Wolff, E. W., and Zucchelli, M.: Eight glacial cycles from an Antarctic ice core, Nature, 429, 623-628, doi:10.1038/nature02599, 2004.

Barnola, J. M., Raynaud, D., Korotkevich, Y. S., and Lorius, C.: Vostok Ice Core Provides 160,000-Year Record of Atmospheric $\mathrm{CO}_{2}$, Nature, 329, 408-414, 1987.

Berger, A. L.: Long-term variations of daily insolation and Quaternary climatic changes, J. Atmos. Sci., 35, 2362-2368, 1978.

Bouttes, N., Paillard, D., Roche, D. M., Brovkin, V., and Bopp, L.: Last Glacial Maximum $\mathrm{CO}_{2}$ and $\delta^{13} \mathrm{C}$ successfully reconciled, Geophys. Res. Lett., 38, L02705, doi:10.1029/2010g1044499, 2011a.

Bouttes, N., Roche, D. M., and Paillard, D.: Systematic study of the fresh water fluxes impact on the carbon cycle, Clim. Past Discuss., 7, 1363-1392, doi:10.5194/cpd-7-1363-2011, 2011 b.

Bozbiyik, A., Steinacher, M., Joos, F., Stocker, T. F., and Menviel, L.: Fingerprints of changes in the terrestrial carbon cycle in response to large reorganizations in ocean circulation, Clim. Past, 7, 319-338, doi:10.5194/cp-7-319-2011, 2011.

Broecker, W. S., Lynch-Stieglitz, J., Clark, E., Hajdas, I., and Bonani, G.: What caused the atmosphere's $\mathrm{CO}_{2}$ content to rise during the last 8000 years?, Geochem. Geophy. Geosy., 2, 1062, doi:2001GC000177, 2001.

Brovkin, V., Bendtsen, J., Claussen, M., Ganopolski, A., Kubatzki, C., Petoukhov, V., and Andreev, A.: Carbon cycle, vegetation, and climate dynamics in the Holocene: Experiments with the CLIMBER-2 model, Global Biogeochem. Cy., 16, 1139, doi:10.1029/2001gb001662, 2002.

Brovkin, V., Ganopolski, A., Archer, D., and Rahmstorf, S.: Lowering of glacial atmospheric $\mathrm{CO}_{2}$ in response to changes in oceanic circulation and marine biogeochemistry, Paleoceanography, 22, Pa4202, doi:10.1029/2006pa001380, 2007.

Calov, R., Ganopolski, A., Petoukhov, V., Claussen, M., and Greve, R.: Large-scale instabilities of the Laurentide ice sheet simulated in a fully coupled climate-system model, Geophys. Res. Lett., 29, 2216, doi:10.1029/2002g1016078, 2002. 
Catubig, N. R., Archer, D. E., Francois, R., deMenocal, P., Howard, W., and Yu, E. F.: Global deep-sea burial rate of calcium carbonate during the last glacial maximum, Paleoceanography, 13, 298-310, doi:10.1029/98pa00609, 1998.

Chikamoto, M. O., Matsumoto, K., and Ridgwell, A.: Response of deep-sea $\mathrm{CaCO}_{3}$ sedimentation to Atlantic meridional overturning circulation shutdown, J. Geophys. Res.-Biogeo., 113, G03017, doi:10.1029/2007jg000669, 2008.

Denman, K. L., Brasseur, G., Chidthaisong, A., Ciais, P., Cox, P. M., Dickinson, R. E., Hauglustaine, D., Heinze, C., Holland, E., Jacob, D., Lohmann, U., Ramachandran, S., Silva Dias, P. L., Wofsy, S. C., and Zhang, X.: Couplings Between Changes in the Climate System and Biogeochemistry, in: The Physical Science Basis, Contribution of Working Group I to the Fourth Assessment Report of the Intergovernmental Panel on Climate Change, edited by: Solomon, S., Qin, D., Manning, M., Chen, Z., Marquis, M., Averyt, K. B., Tignor, M., and Miller, H. L., Cambridge University Press, Cambridge, 501-587, 2007.

Dutay, J. C., Bullister, J. L., Doney, S. C., Orr, J. C., Najjar, R., Caldeira, K., Campin, J. M., Drange, H., Follows, M., Gao, Y., Gruber, N., Hecht, M. W., Ishida, A., Joos, F., Lindsay, K., Madec, G., Maier-Reimer, E., Marshall, J. C., Matear, R. J., Monfray, P., Mouchet, A., Plattner, G. K., Sarmiento, J., Schlitzer, R., Slater, R., Totterdell, I. J., Weirig, M. F., Yamanaka, Y., and Yool, A.: Evaluation of ocean model ventilation with CFC-11: comparison of 13 global ocean models, Ocean Modell., 4, 89-120, doi:10.1016/s1463-5003(01)00013-0, 2002.

Fletcher, S. E. M., Gruber, N., Jacobson, A. R., Gloor, M., Doney, S. C., Dutkiewicz, S., Gerber, M., Follows, M., Joos, F., Lindsay, K., Menemenlis, D., Mouchet, A., Muller, S. A., and Sarmiento, J. L.: Inverse estimates of the oceanic sources and sinks of natural $\mathrm{CO}_{2}$ and the implied oceanic carbon transport, Global Biogeochem. Cy., 21, GB1010, doi:10.1029/2006gb002751, 2007.

Ganopolski, A. and Rahmstorf, S.: Rapid changes of glacial climate simulated in a coupled climate model, Nature, 409, 153 158,2001

Ganopolski, A., Calov, R., and Claussen, M.: Simulation of the last glacial cycle with a coupled climate ice-sheet model of intermediate complexity, Clim. Past, 6, 229-244, doi:10.5194/cp-6-2292010, 2010.

Greve, R.: Application of a polythermal three-dimensional ice sheet model to the Greenland Ice Sheet: Response to steady-state and transient climate scenarios, J. Climate, 10, 901-918, 1997.

Gruber, N., Gloor, M., Fletcher, S. E. M., Doney, S. C., Dutkiewicz, S., Follows, M. J., Gerber, M., Jacobson, A. R., Joos, F., Lindsay, K., Menemenlis, D., Mouchet, A., Muller, S. A., Sarmiento, J. L., and Takahashi, T.: Oceanic sources, sinks, and transport of atmospheric $\mathrm{CO}_{2}$, Global Biogeochem. Cy., 23, GB1005, doi:10.1029/2008gb003349, 2009.

Hain, M. P., Sigman, D. M., and Haug, G. H.: Carbon dioxide effects of Antarctic stratification, North Atlantic Intermediate Water formation, and subantarctic nutrient drawdown during the last ice age: Diagnosis and synthesis in a geochemical box model, Global Biogeochem. Cy., 24, Gb4023, doi:10.1029/2010gb003790, 2010.

Hodell, D. A., Charles, C. D., and Sierro, F. J.: Late Pleistocene evolution of the ocean's carbonate system, Earth Planet. Sc. Lett., 192, 109-124, 2001.
Jaccard, S. L. and Galbraith, E. D.: Large climate-driven changes of oceanic oxygen concentrations during the last deglaciation, Nat. Geosci., 5, 151-156, doi:10.1038/ngeo1352, 2012.

Kaplan, J. O., Prentice, I. C., Knorr, W., and Valdes, P. J.: Modeling the dynamics of terrestrial carbon storage since the Last Glacial Maximum, Geophys. Res. Lett., 29, 2074, doi:10.1029/2002gl015230, 2002.

Kleinen, T., Brovkin, V., von Bloh, W., Archer, D., and Munhoven, G.: Holocene carbon cycle dynamics, Geophys. Res. Lett., 37, L02705, doi:10.1029/2009GL041391, 2010.

Kleypas, J. A.: Modeled estimates of global reef habitat and carbonate production since the last glacial maximum, Paleoceanography, 12, 533-545, 1997.

Köhler, P. and Fischer, H.: Simulating low frequency changes in atmospheric $\mathrm{CO}_{2}$ during the last 740000 years, Clim. Past, 2, 57-78, doi:10.5194/cp-2-57-2006, 2006.

Kohfeld, K. E. and Ridgwell, A.: Glacial-interglacial variability in atmospheric $\mathrm{CO}_{2}$, in: Surface Ocean/Lower Atmosphere Processes, Geophysical Monograph Series 37, edited by: Le Quéré, C. and Saltzman, E., American Geophysical Union, Washington, DC, 2009.

Kurahashi-Nakamura, T., Abe-Ouchi, A., and Yamanaka, Y.: Effects of physical changes in the ocean on the atmospheric $p \mathrm{CO}_{2}$ : glacial-interglacial cycles, Clim. Dynam., 35, 713-719, doi:10.1007/s00382-009-0609-5, 2010.

Lisiecki, L. E., Raymo, M. E., and Curry, W. B.: Atlantic overturning responses to Late Pleistocene climate forcings, Nature, 456, 85-88, doi:10.1038/nature07425, 2008.

Mahowald, N., Kohfeld, K., Hansson, M., Balkanski, Y., Harrison, S. P., Prentice, I. C., Schulz, M., and Rodhe, H.: Dust sources and deposition during the last glacial maximum and current climate: A comparison of model results with paleodata from ice cores and marine sediments, J. Geophys. Res.-Atmos., 104, 15895-15916, 1999.

Marchal, O., Stocker, T. F., Joos, F., Indermuhle, A., Blunier, T., and Tschumi, J.: Modelling the concentration of atmospheric $\mathrm{CO}_{2}$ during the Younger Dryas climate event, Clim. Dynam., 15, 341354, 1999.

Martinez-Garcia, A., Rosell-Mele, A., Geibert, W., Gersonde, R., Masque, P., Gaspari, V., and Barbante, C.: Links between iron supply, marine productivity, sea surface temperature, and $\mathrm{CO}_{2}$ over the last 1.1 Ma, Paleoceanography, 24, Pa1207, doi:10.1029/2008pa001657, 2009.

Menviel, L., Timmermann, A., Mouchet, A., and Timm, O.: Meridional reorganizations of marine and terrestrial productivity during Heinrich events, Paleoceanography, 23, Pa1203, doi:10.1029/2007pa001445, 2008.

Monnin, E., Steig, E. J., Siegenthaler, U., Kawamura, K., Schwander, J., Stauffer, B., Stocker, T. F., Morse, D. L., Barnola, J. M., Bellier, B., Raynaud, D., and Fischer, H.: Evidence for substantial accumulation rate variability in Antarctica during the Holocene, through synchronization of $\mathrm{CO}_{2}$ in the Taylor Dome, Dome C and DML ice cores, Earth Planet. Sc. Lett., 224, 45-54, doi:10.1016/j.eps1.2004.05.007, 2004.

Munhoven, G.: Glacial-interglacial changes of continental weathering: estimates of the related $\mathrm{CO}_{2}$ and $\mathrm{HCO}_{3}^{-}$flux variations and their uncertainties, Global Planet. Change, 33, 155-176, 2002. 
Obata, A.: Climate-carbon cycle model response to freshwater discharge into the North Atlantic, J. Climate, 20, 5962-5976, doi:10.1175/2007jcli1808.1, 2007.

Oliver, K. I. C., Hoogakker, B. A. A., Crowhurst, S., Henderson, G. M., Rickaby, R. E. M., Edwards, N. R., and Elderfield, H.: A synthesis of marine sediment core $\delta^{13} \mathrm{C}$ data over the last 150000 years, Clim. Past, 6, 645-673, doi:10.5194/cp-6-6452010, 2010.

Parekh, P., Joos, F., and Muller, S. A.: A modeling assessment of the interplay between aeolian iron fluxes and ironbinding ligands in controlling carbon dioxide fluctuations during Antarctic warm events, Paleoceanography, 23, Pa4202, doi:10.1029/2007pa001531, 2008.

Peacock, S., Lane, E., and Restrepo, J. M.: A possible sequence of events for the generalized glacial-interglacial cycle, Global Biogeochem. Cy., 20, GB2010, doi:2010.1029/2005GB002448, 2006.

Petoukhov, V., Ganopolski, A., Brovkin, V., Claussen, M., Eliseev, A., Kubatzki, C., and Rahmstorf, S.: CLIMBER-2: a climate system model of intermediate complexity, Part I: model description and performance for present climate, Clim. Dynam., 16, 117, 2000.

Rickaby, R. E. M., Elderfield, H., Roberts, N., Hillenbrand, C. D., and Mackensen, A.: Evidence for elevated alkalinity in the glacial Southern Ocean, Paleoceanography, 25, Pa1209, doi:10.1029/2009pa001762, 2010.

Ridgwell, A. J. and Watson, A. J.: Feedback between aeolian dust, climate, and atmospheric $\mathrm{CO}_{2}$ in glacial time, Paleoceanography, 17, 1059, doi:1010.1029/2001PA000729, 2002.

Ridgwell, A. J., Watson, A. J., Maslin, M. A., and Kaplan, J. O.: Implications of coral reef buildup for the controls on atmospheric $\mathrm{CO}_{2}$ since the Last Glacial Maximum, Paleoceanography, 18, 1083, doi:10.1029/2003PA000893, 2003.

Sabine, C. L., Feely, R. A., Gruber, N., Key, R. M., Lee, K., Bullister, J. L., Wanninkhof, R., Wong, C. S., Wallace, D. W. R., Tilbrook, B., Millero, F. J., Peng, T. H., Kozyr, A., Ono, T., and Rios, A. F.: The oceanic sink for anthropogenic $\mathrm{CO}_{2}$, Science, 305, 367-371, doi:10.1126/science.1097403, 2004.

Schaefer, K., Zhang, T., Bruhwiler, L., and Barrett, A. P.: Amount and timing of permafrost carbon release in response to climate warming, Tellus B, 63, 165-180, doi:10.1111/j.16000889.2011.00527.x, 2011.
Schmittner, A.: Decline of the marine ecosystem caused by a reduction in the Atlantic overturning circulation, Nature, 434, 628633, doi:10.1038/nature03476, 2005.

Schmittner, A. and Galbraith, E. D.: Glacial greenhouse-gas fluctuations controlled by ocean circulation changes, Nature, 456, 373-376, doi:10.1038/nature07531, 2008.

Sigman, D. M. and Boyle, E. A.: Glacial/interglacial variations in atmospheric carbon dioxide, Nature, 407, 859-869, 2000.

Skinner, L. C.: Glacial - interglacial atmospheric $\mathrm{CO}_{2}$ change: a simple "hypsometric effect" on deep-ocean carbon sequestration?, Clim. Past Discuss., 2, 711-743, doi:10.5194/cpd-2-7112006, 2006.

Skinner, L. C.: Glacial-interglacial atmospheric $\mathrm{CO}_{2}$ change: a possible "standing volume" effect on deep-ocean carbon sequestration, Clim. Past, 5, 537-550, doi:10.5194/cp-5-537-2009, 2009.

Toggweiler, J. R., Russell, J. L., and Carson, S. R.: Midlatitude westerlies, atmospheric $\mathrm{CO}_{2}$, and climate change during the ice ages, Paleoceanography, 21, PA2005, doi:10.1029/2005PA001154, 2006.

Waelbroeck, C., Labeyrie, L., Michel, E., Duplessy, J. C., McManus, J. F., Lambeck, K., Balbon, E., and Labracherie, M.: Sea-level and deep water temperature changes derived from benthic foraminifera isotopic records, Quaternary Sci. Rev., 21, 295305, 2002.

Watson, A. J., Bakker, D. C. E., Ridgwell, A. J., Boyd, P. W., and Law, C. S.: Effect of iron supply on Southern Ocean $\mathrm{CO}_{2}$ uptake and implications for glacial atmospheric $\mathrm{CO}_{2}$, Nature, 407, 730733, 2000.

Willey, D. A., Fine, R. A., Sonnerup, R. E., Bullister, J. L., Smethie, W. M., and Warner, M. J.: Global oceanic chlorofluorocarbon inventory, Geophys. Res. Lett., 31, L01303, doi:10.1029/2003g1018816, 2004.

Yu, J. M., Broecker, W. S., Elderfield, H., Jin, Z. D., McManus, J., and Zhang, F.: Loss of Carbon from the Deep Sea Since the Last Glacial Maximum, Science, 330, 1084-1087, doi:10.1126/science.1193221, 2010.

Zimov, N. S., Zimov, S. A., Zimova, A. E., Zimova, G. M., Chuprynin, V. I., and Chapin, F. S.: Carbon storage in permafrost and soils of the mammoth tundra-steppe biome: Role in the global carbon budget, Geophys. Res. Lett., 36, L02502, doi:10.1029/2008g1036332, 2009. 